\title{
Expression and potential role of cellular retinol binding protein $I$ in psoriasis
}

\author{
Gaetana Costanza ${ }^{1,4, *}$, Elena Doldo ${ }^{1, *}$, Amedeo Ferlosio ${ }^{1, *}{ }^{,}$Chiara Tarquini ${ }^{1}$, Daniela \\ Passeri $^{1}$, Raffaella Cascella ${ }^{2}$, Mauro Bavetta ${ }^{3}$, Alessandro Di Stefani ${ }^{3}$, Claudio \\ Bonifati ${ }^{4}$, Sara Agostinelli ${ }^{1}$, Federica Centofanti ${ }^{1}$, Emiliano Giardina ${ }^{2}$, Elena \\ Campione $^{3}$, Luca Bianchi ${ }^{3}$, Pietro Donati ${ }^{4}$, Aldo Morrone ${ }^{4}$ and Augusto Orlandi ${ }^{1,5}$ \\ ${ }^{1}$ Anatomic Pathology Unit, Department of Biomedicine and Prevention, Tor Vergata University of Rome, Rome, Italy \\ ${ }^{2}$ Genetics Laboratory, Department of Biomedicine and Prevention, Tor Vergata University of Rome, Rome, Italy \\ ${ }^{3}$ Dermatology Unit, Tor Vergata University of Rome, Policlinic of Tor Vergata of Rome, Rome, Italy \\ ${ }^{4}$ San Gallicano Dermatology Institute, Rome, Italy \\ ${ }^{5}$ Catholic University "Our Lady of Good Counsel", Tirana, Albania \\ "These authors have contributed equally to this work \\ Correspondence to: Augusto Orlandi, email: orlandi@uniroma2.it \\ Keywords: CRBPl; retinoids; imiquimod-induced psoriasis; keratinocyte proliferation \\ Received: July 15, $2018 \quad$ Accepted: October 25, $2018 \quad$ Published: December 04, 2018 \\ Copyright: Costanza et al. This is an open-access article distributed under the terms of the Creative Commons Attribution License \\ 3.0 (CC BY 3.0), which permits unrestricted use, distribution, and reproduction in any medium, provided the original author and \\ source are credited.
}

\section{ABSTRACT}

Psoriasis is a diffuse chronic skin disorder characterized from accelerated epidermal turnover and inflammatory cell infiltrate. Retinoids influence keratinocyte proliferation and differentiation as well as inflammatory response. Cellular retinol binding protein (CRBPI) regulates intracellular vitamin A bioavailability and contributes to maintain skin homeostasis. The aim of present study was to investigate the expression of CRBPI and its role in the pathogenesis of skin psoriasis. Immunohistochemistry revealed more diffuse and increased CRBPI expression in all epidermal layers of human psoriatic lesions except in the stratum corneum. An imiquimod-induced psoriatic-like model documented the increase of skin lesional area and severity index score as well as of the severity of microscopic features as parakeratosis, papillomatosis and spongiosis in CRBPI-knockout compared to wildtype mice, associated to the increased keratinocyte CK17 and Ki-67 expression and the reduction of CK1, CRABPII and RXRa. Gene array of imiquimod-induced psoriatic skin documented the greater up-regulation of EGF/PDGF-related genes and downregulation of EGR1 and pro-inflammatory IL-related genes in CRBPI-knockout compared to wild-type mice. Finally, CRBPI transfection in HaCaT cells increased AKT and NF-KB-related genes and proteins and down-regulated IL-2, IL-6 and IL-8 pro-inflammatory signalling. Although not recognized as a psoriatic susceptibility gene in our cohort of patients, the present data strongly supported the potential role of CRBPI to sustain keratinocyte proliferation and differentiation and to counteract pro-inflammatory genes expression in psoriatic lesions.

\section{INTRODUCTION}

Psoriasis is one of the most frequent skin disorders, affecting about $2-3 \%$ of the general population [1].
Psoriasis represents a life-long patients' affliction, with a considerable impact on the quality of life [2, 3]. Psoriasis is characterized by epidermal hyperproliferation, abnormal terminal keratinocyte differentiation and inflammation 
[4]. Risk and genetic factors interact with environmental agents such as drugs, stress or infections $[1,3,5,6]$ but still many aspects of the pathogenesis of psoriasis remain partially unknown. Retinoids regulate proliferation and differentiation of skin keratinocytes [7]. Cellular retinol binding protein I (CRBPI) is a cytosolic carrier of retinol essential for its homeostasis [8-10]. CRBPI expression is indispensable for embryonic development, growth and survival of vertebrates [9]. In the skin, CRBPI contributes to keratinocyte growth and differentiation likely by regulating intracellular retinol bioavailability [11]. Altered expression of retinoid-related proteins and receptors have been reported in the psoriatic skin [12-14], but data concerning CRBPI expression were controversial [13, 15]. In fact, first studies on potential CRBPI involvement in psoriasis showed its decreased expression in psoriatic compared to non-lesional skin both in basal condition and after retinoids treatment, with a relevant inter-individual variability [15]. Successively, Bush et al., [12] reported an increased CRBPI expression in psoriasis. In another study, the amount of CRBPI protein was reported to be similar in non-lesional and lesional psoriatic skin cells [13]. CRBPI gene $(R B P 1)$ maps on chromosome $3 \mathrm{q} 2$ and clusters near PSORS5 locus, part of psoriasis susceptibility loci [16]. In the present study, we investigated CRBPI expression in lesional and non-lesional skin of a cohort of patients affected by moderate to severe plaque type psoriasis. To better investigate the effective role of CRBPI expression in psoriatic lesion development and keratinocyte biology, we used an imiquimod-induced model of psoriasis $[8,17]$ in CRBPI-knockout mice and CRBPI-transfected $\mathrm{HaCaT}$ cells. Our results strongly support a favorable role of CRBPI expression in the maintenance of skin integrity in psoriasis by sustaining keratinocytes proliferation, differentiation and the expression of pro-inflammatory cytokines, suggesting CRBPI-mediated function a therapeutic target to prevent epidermal damage in psoriasis.

\section{RESULTS}

\section{CRBPI overexpression is characteristic of psoriatic epidermis}

We investigated CRBPI expression in human skin by immunohistochemistry. In normal epidermis, keratinocyte CRBPI immunodetection was faint and mostly cytoplasmatic, stronger in the basal than in superficial layers and absent in the corneum (Figure 1A). In psoriatic lesions, CRBPI immunoexpression was more diffuse increased compared to normal skin $(\mathrm{p}<0.00001$ Figure 1B, 1C). CRBPI expression was absent in psoriatic parakeratotic cells. We also evaluated other parameters involved in the aberrant keratinocyte proliferation/ differentiation of psoriasis. As reported in Supplementary Figure 1, epidermal Ki-67 and CK17 immunoexpression markedly increased in psoriasis compared to normal skin, $\left({ }^{* *} p<0.01\right)$ according to previous studies [3], whereas RXR $\alpha$ and CK1 expression decreased ${ }^{* *} \mathrm{p}<0.05$; Supplementary Figure 1). Finally, epidermal CRABPII expression was also increased in psoriatic lesions compared to normal skin ${ }^{* *} p<0.01$; Supplementary Figure 1).

\section{Imiquimod-induced skin inflammation is more severe in CRBPI-knockout mice}

To define a potential protective or favouring role of CRBPI in the development of psoriatic lesions, we investigated imiquimod-induced back skin inflammation, a well-known experimental model of psoriasis $[17,18]$ induced in CRBPI-knockout and wild-type C57BL/6 mice. After six days of imiquimod treatment, both groups showed typical skin signs of psoriasis (Figure 2A). Clinical evaluation of parameters such as erythema, scales and epidermal thickness revealed the greater increase in CRBPI-knockout compared to wild-type mice
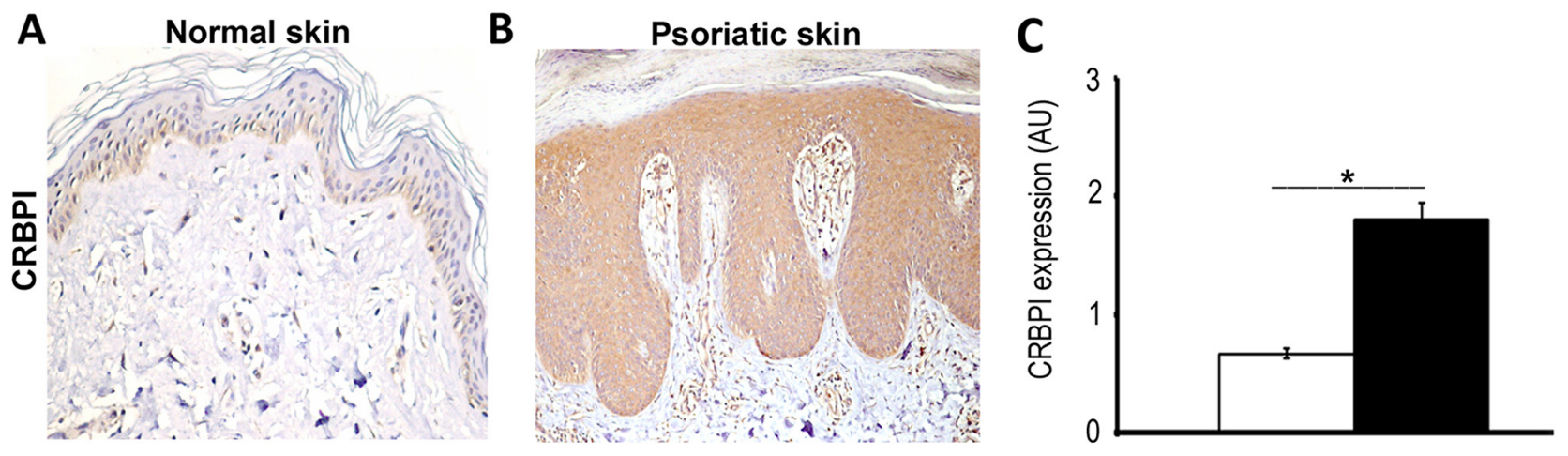

Figure 1: Expression of CRBPI in normal and psoriatic skin. (A) Representative image of the weak CRBPI immunoexpression, more in the basal layer of the normal skin epidermis; whereas (B) CRBPI expression strongly increases in psoriatic epidermis. (C) Bar graph shows the semiquantitative evaluation of epidermal CRBPI immunostaining. Results are expressed as mean values \pm SEM. ${ }^{*} \mathrm{p}<0.00001$ at Student's $t$-test. 
starting from days $2-3\left({ }^{*} p<0.05 ;{ }^{* *} p<0.01 ;{ }^{* * *} p<0.001\right.$; respectively; Figure 2B). Also the cumulative psoriasis area and severity index (PASI) score was greater in CRBPI-knockout compared to wild-type mice (Figure 2B). Vehicle-treated skin of both mouse phenotypes as control did not reveal any sign of inflammation. Microscopic evaluation of Haematoxylin\&Eosin-stained sections showed in untreated wild-type and CRBPI-knockout epidermis the presence of thin basal and granular layers and a more evident stratum corneum (Figure 2C). After 6 days of imiquimod treatment, semiquantitative analysis revealed that parakeratosis, papillomatosis and spongiosis were more severe in CRBPI-knockout compared to wildtype mice $\left({ }^{*} p<0.05 ;^{* *} p<0.01 ;{ }^{* * *} p<0.001\right.$; Figure 2D). Moreover, the number of epidermal layers was greater in CRBPI-knockout compared to wild-type mice $\left({ }^{* * *} p<0.001\right.$; Figure 2F). In summary, imiquimod induced more severe psoriasis-like skin lesions in CRBPI-knockout than in wild-type mice.

\section{Expression of CRABPII, RXR $\alpha$ and other psoriasis biomarkers is decreased in CRBPI- knockout mice}

We investigated the expression of retinoid receptors and psoriatic biomarkers in normal and imiquimodtreated mouse skin. CRBPI immunostaining detected in the skin of wild-type C57BL/6 mice but not in CRBPIknockout mice, as expected (Figure 3A). After six days of imiquimod treatment, CRBPI expression increased in the epidermis of wild-type compared to untreated control mice $(p<0.0001$, Figure $3 B)$, and still absent in CRBPI-knockout mice. Interestingly, we documented a reduced CRABPII and RXR $\alpha$ epidermal expression in imiquimod-treated CRBPI-knockout compared to wildtype mice (Figure $3 \mathrm{~A}$ and $3 \mathrm{~B}$ ). As reported in Figure $4 \mathrm{~A}$ and $4 \mathrm{~B}$, epidermis of vehicle-treated wild-type and CRBPI-knockout mice displayed a similar Ki-67, CK1 and CK17 immunopositivity. After 6 days of imiquimod treatment, the increase of $\mathrm{Ki}-67$ and $\mathrm{CK} 17$ positivity and the reduction of CK1 expression were more evident in the epidermis of CRBPI-knockout compared to wild-type mice (Figure 4A and 4B). These results strongly supported the hypothesis that loss of CRBPI gene favors the severity of psoriatic lesions and negatively influences CRABPII and $\mathrm{RXR} \alpha$ expression.

\section{CRBPI loss influences EGF/PDGF-related gene levels in vivo}

To better investigate gene pathways influenced by CRBPI expression in vivo, we performed gene array of imiquimod-treated skin of wild type and CRBPI-knockout mice. As shown in Figure 5A and 5B, imiquimod-induced psoriatic skin inflammation in CRBPI-knockout mice associated with a greater up-regulation of the following genes: activating transcription factor 1 (ATF1), BCL2associated agonist of cell death (BAD), Braf transforming gene (BRAF), Casitas B-lineage lymphoma (CBLB), cyclin D1 (CCND1), conserved helix-loop-helix ubiquitous kinase (CHUK), casein kinase 2, alpha 1 polypeptide (CSNK2A1), FBJ osteosarcoma oncogene (FOS), glycogen synthase kinase 3 beta (GSK3B), interleukin 2 (IL-2), potassium voltage-gated channel, subfamily $\mathrm{H}$ (eag-related) member 8 (KCNH8), lymphotoxin A (LTA), mitogen-activated protein kinase kinase 1 (MAP2K1), mitogen-activated protein kinase 8 (MAPK8), matrix metallopeptidase 7 (MMP7), noncatalytic region of tyrosine kinase adaptor protein 2 (NCK2), phosphatidylinositol 3-kinase, regulatory subunit, polypeptide 2 (p85 beta) (PIK3R2), RAS p21 protein activator 1 (RASA1). Instead, early growth response 1 (EGR1) was down-regulated. Overall, our results suggested that loss of CRBPI expression influences epidermal growth factor-platelet-derived growth factor (EGF/PDGF)-related genes level, likely involved in keratinocyte growth and differentiation and downregulated EGR1, involved in the control of keratinocyte hyperproliferation.

\section{CRBPI transfection restores AKT and NF-kB- related gene and protein levels in $\mathrm{HaCaT}$ cells}

To further investigate CRBPI-related gene signalling, we transfected CRBPI gene in HaCaT cells, an immortalized human keratinocyte line not-expressing CRBPI and analyzed changes of AKT and NF-kBrelated genes (Figure 6). The following genes resulted up-regulated significantly in CBBPI transfected cells: 14-3-3-sigma, M-TOR, AKT1, AKT3, FOXO3, P21, P27, P53, P70, PDK1, BAD, PI3K, P-TEN, CASP9, IKK, COX2, TNF $\alpha$, FASL, INF-y, INFB1, MDR1 and MMP1. Instead, the following genes were down-regulated: BCL2, IL-2, IL-6, IL-8 MYC1, NOS2, VCAM1. Remaining genes analysed were not significantly modified. Blot analysis for IL6, IL8 and pAKT and pERK (p42-44) gave similar results (Figure 6). Those findings strongly supported the hypothesis that CRBPI presence potentially increased some of AKT and NF- $\kappa \mathrm{B}$-related gene and protein expression, probably for the activation in $\mathrm{HaCaT}$ cells of FABP5 and PPR $\beta / \delta$ receptors [19]. Interestingly, in presence of CRBPI some of pro-inflammatory genes were down-regulated, as IL-6 that induces activation of Th cells and controls the balance between Treg cells and Th17 cells [20, 21].

\section{RBPI gene analysis in psoriatic patients}

To investigate the potential role of $R B P I$ as susceptibility gene, biostatistical analysis was performed in a large cohort of psoriatic $(n=400)$ and control subjects $(n=490)$. As reported in haplotype analysis 
(Supplementary Tables 1 and 2), genetic association and allele/genotype frequencies of the selected SNPs did not statistically vary $(p>0.05)$. Haplotype analysis performed on the SNPs of interest revealed several haplotypes combinations. As reported in Supplementary Table 2, the identified haplotypes failed to show a significant association between psoriatic and tested SNPs, at least in our cohort of patients.

\section{DISCUSSION}

In our study, we documented the increased CRBPI expression in human skin psoriatic lesions and the greater severity of lesions in CRBPI-knockout mice in an imiquimod-induced model of psoriasis. CRBPI is a small cytosolic $15 \mathrm{KDa}$ protein widely expressed and evolutionarily conserved in many tissues [7]. CRBPI acts as chaperone protein and regulates uptake and subsequent esterification of retinol and its bioavailability $[9,10]$. Topical or systemic retinoid treatment contributes to the management of patients with skin psoriasis [22]. The increased CRBPI expression in human psoriatic epidermis confirms previous studies [12], and likely favours the keratinocyte conversion of retinol in retinoic acid, the most active retinoid in the skin [12]. It has been also reported that CRBPI expression in epidermis is
A
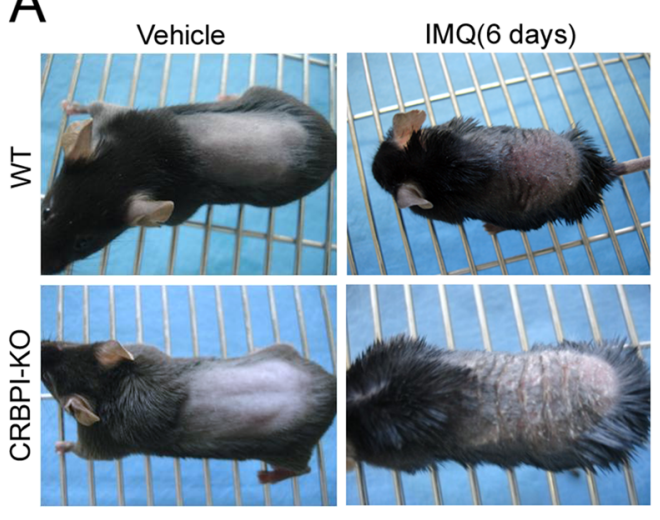

C

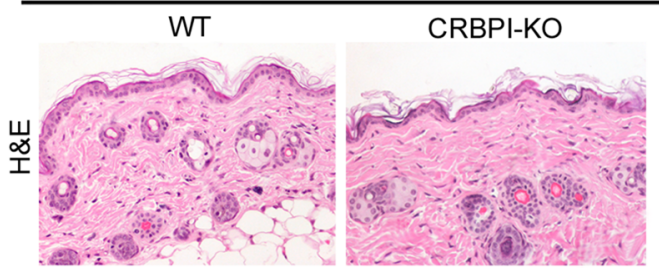

E

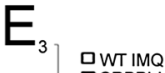

2.

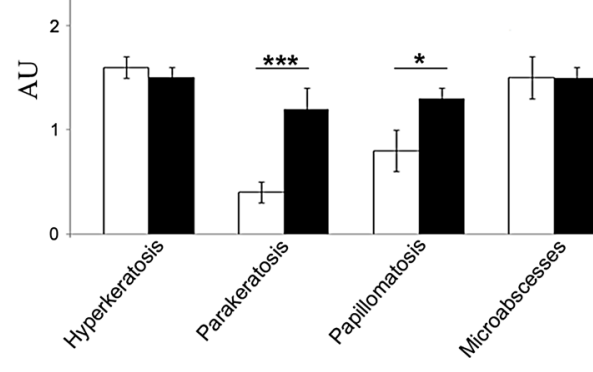

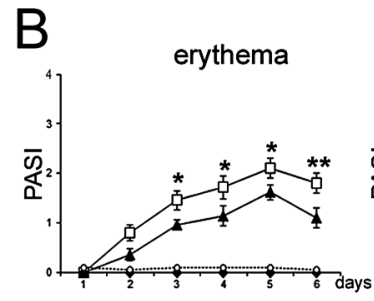
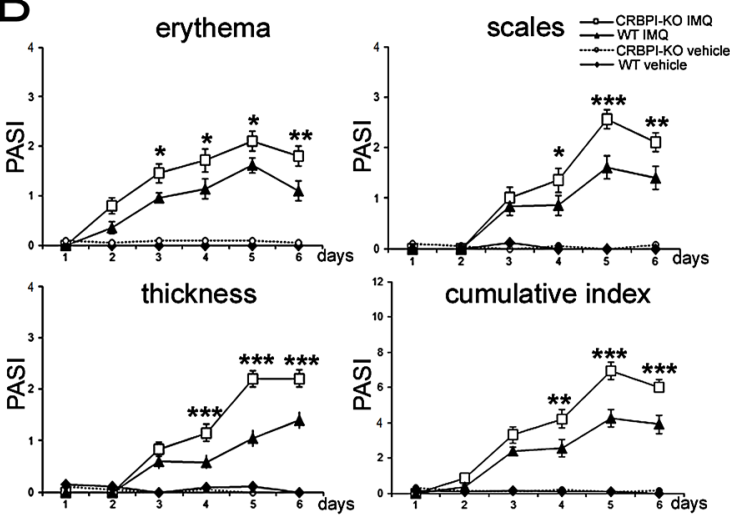

D
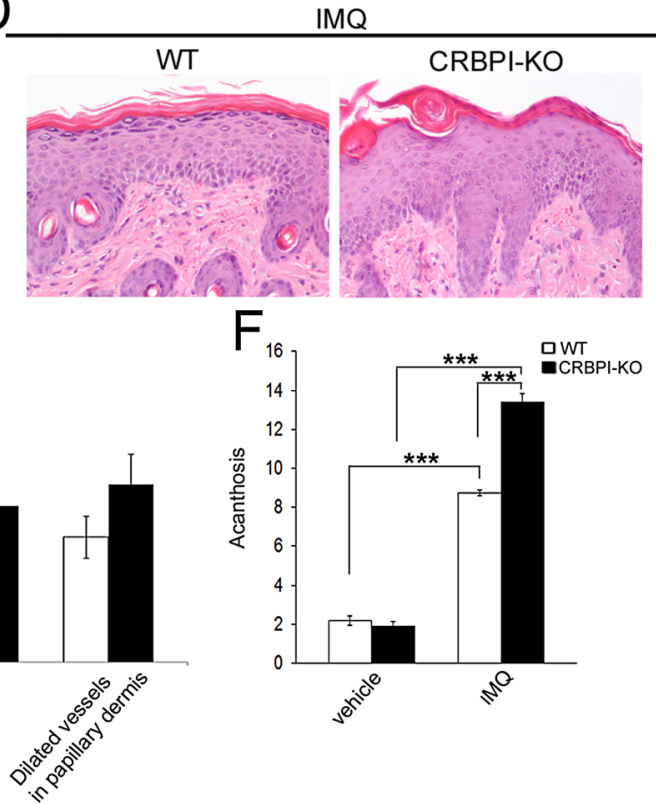

Figure 2: Imiquimod treatment induces more severe psoriasis-like lesions in CRBPI-knockout mice. (A) Back skin of wild-type (WT) and CRBPI-knockout (KO) mice after 6 days of treated control cream (vehicle) or imiquimod (IMQ); (B) daily scoring of erythema, scaling and thickness cumulative score (PASI) shows an early increase in imiquimod treated CRBPI-knockout skin compared to wild-type mice; (C-D) representative microscopic images of (C) vehicle control and (D) imiquimod-treated wild-type and CRBPI-knockout mouse skin, Haematoxylin\&Eosin (H\&E) staining; original magnification; 200X; (E-F) bar graphs showing semiquantitative evaluation of microscopic parameters of skin psoriasis in imiquimod-treated wild-type and CRBPI-knockout mice after six days. Results are expressed as mean values \pm SEM ( $=8$ mice per group); ${ }^{*} p<0.05 ;{ }^{* *} p<0.01 ;{ }^{* * *} p<0.001$ at Student's $t$-test. Original magnification, $200 \mathrm{X}$. 
up-regulated after the exposure to retinoids and retinol [23-25], suggesting a key role in their efficacy. Retinoids effects are likely related to the transcription of genes involved in cell proliferation and differentiation [25, 26]. Although CRBPI deficiency has no apparent consequence on development and post-natal life, CRBPI-mediated retinoid bioavailability is likely to sustain proliferation and differentiation of keratinocytes [8, 27, 28]. Psoriasis is a hyperproliferative epidermal disorder characterized by spinous layer hyperplasia and incomplete differentiation of granular and cornified layers [29]. Keratinocyte cycle time is reduced approximately eight fold in psoriatic compared to normal skin and the number of dividing cells is greatly increased, resulting in a hyperplastic epithelium [30]. Abnormal proliferation is also confirmed by the increased suprabasal Ki-67 positivity, otherwise observed only in the basal layer of normal epidermis [29, 31]. In addition, an aberrant keratinocyte differentiation for the accelerated turnover also occurs in psoriatic epidermis [4]. CK1 and CK17 are markers to evaluate keratinocyte

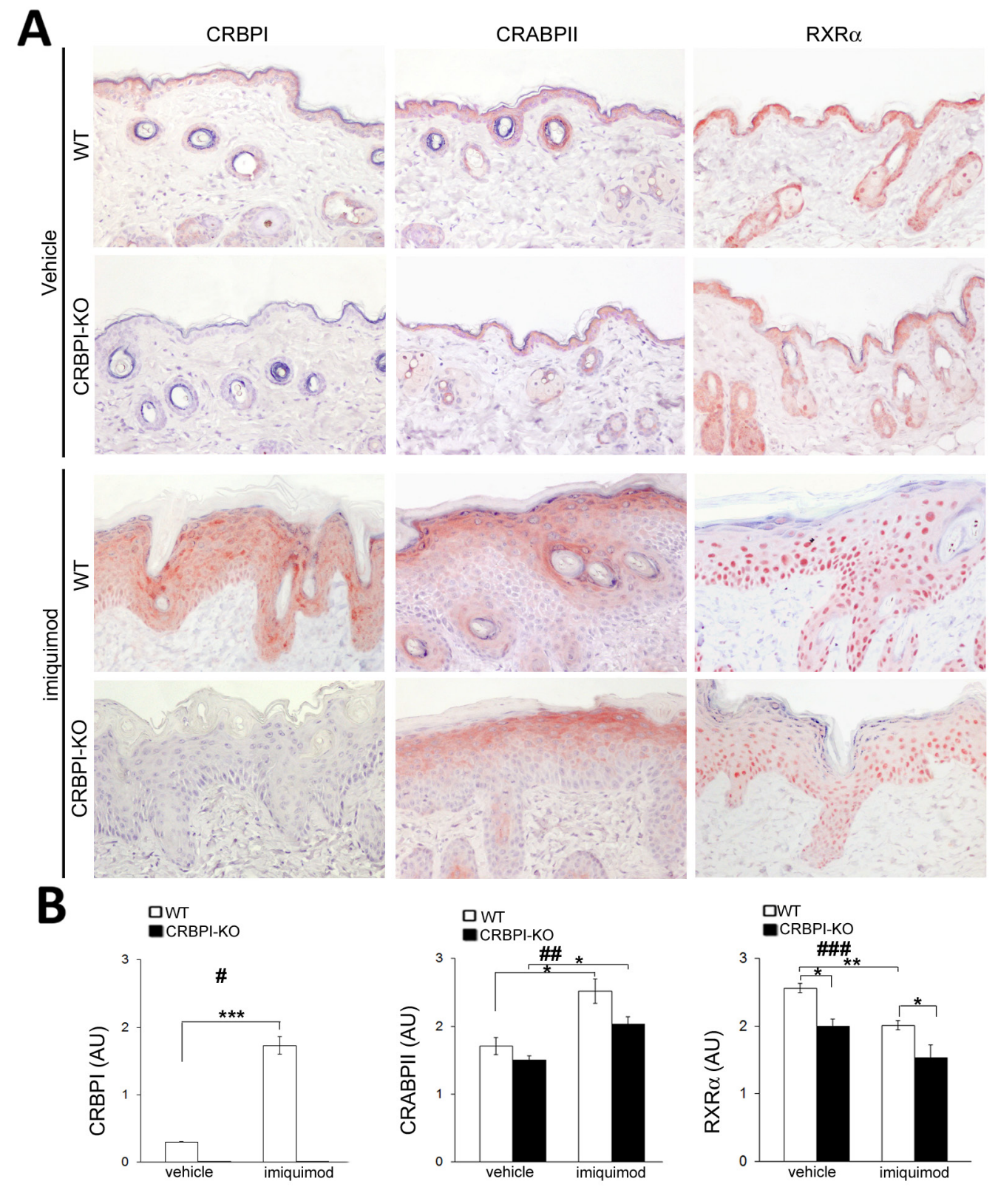

Figure 3: Evaluation of CRBPI, CRABPII and RXR $\alpha$ expression in imiquimod-induced psoriatic skin of CRBPIknockout and wild-type mice. (A) Representative CRBPI, CRABP-II and RXR $\alpha$ immunostainings of wild-type (WT) and CRBPIknockout (KO) mice skin after 6 days of treatment with control cream (vehicle) or imiquimod (IMQ). Original magnification 200X; (B) Bar graphs show the semiquantitative evaluation of CRBPI, CRABPII and RXR $\alpha$ immunostainings. Results are expressed as mean values \pm SEM ( $=8$ mice per group); ANOVA ${ }^{\#} p<0.005,{ }^{\#} p<0.0005,{ }^{\# \#} p<0.000005 .{ }^{*} p<0.05 ;{ }^{* *} p<0.01 ;{ }^{* * *} p<0.001$ at Student's $t$-test. 
differentiation and CK17 reduction considered an index of efficacy of anti-psoriatic treatment [21, 32]. To better investigate the role of CRBPI in psoriasis, we induced skin lesions by imiquimod in mice, a diffuse experimental model of psoriasis [17, 18]. Imiquimod, a ligand for TLR7 and TLR8, is a potent immune activator also used for the treatment of virus-associated skin abnormalities as well as (pre)cancerous skin lesions and superficial basal cell carcinomas [33]. Imiquimod-induced psoriasis- like inflammation in the mouse skin recapitulates many clinical and microscopic hallmarks of human psoriasis, [34]. We documented that imiquimod induces more severe skin lesions in CRBPI-knockout compared to wildtype mice. In particular, early after treatment, thickness, hyperkeratosis, erythema, scaling were significantly increased in imiquimod-treated CRBPI-knockout compared with wild-type mice. Also microscopic features of psoriasis, as acanthosis, parakeratosis, papillomatosis

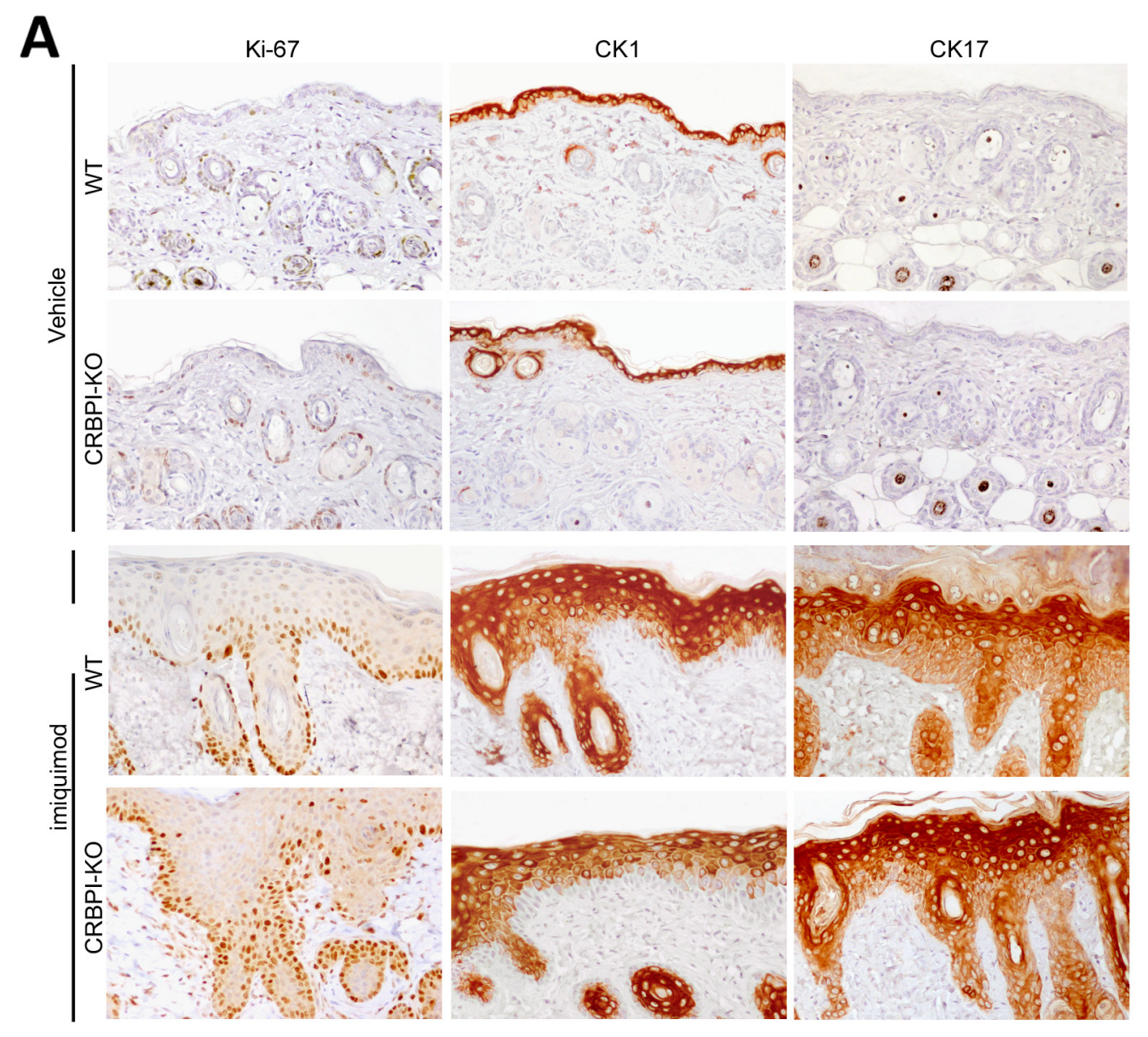

B
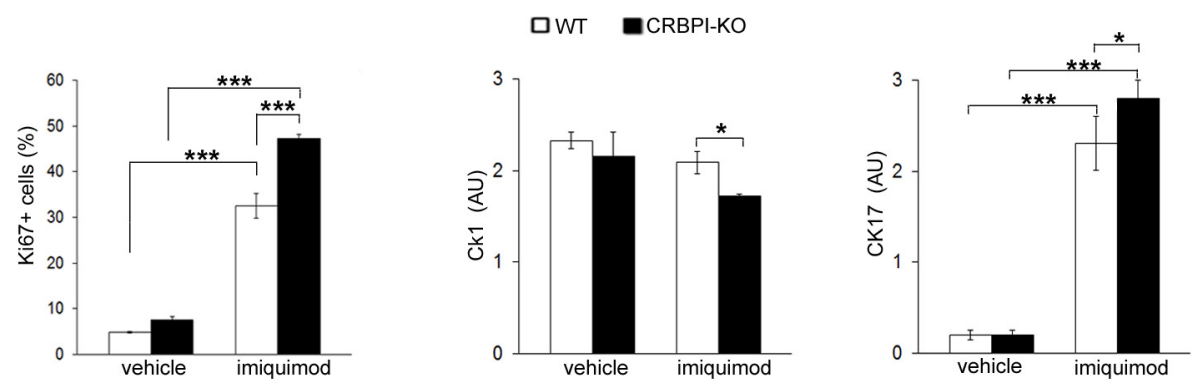

Figure 4: CRBPI gene loss influences epidermal proliferation and expression of differentiation markers. (A) Representative Ki-67, CK1 and CK7 immunostainings of wild-type (WT) and CRBPI-knockout (KO) back skin after 6 days of daily treatment with control cream (vehicle) or imiquimod (IMQ); (B) bar graphs showing the semiquantitative evaluation of Ki-67, CK1 and CK17 immunostainings; results are expressed as mean values \pm SEM (8 mice per group); ANOVA ${ }^{\#} p<0.05,{ }^{\#} p<0.0005,{ }^{\# \#} p<0.000005$. ${ }^{*} p<0.05 ;{ }^{* *} p<0.01 ;{ }^{* * *} p<0.001$ at Student's $t$-test. 
and spongiosis [35], increased more in imiquimod-induced lesions of CRBPI-knockout compared to wild-type mice. As concerning skin psoriasis biomarkers, we observed greater Ki-67 and CK17 and lower CK1 expression in imiquimod-induced psoriasis like lesions of CRBPIknockout compared to wild-type mice. Our results strongly supported the hypothesis that the absence of CRBPI expression favors a more severe phenotype of skin psoriasis. Beside the alteration of psoriasis biomarkers, we documented in imiquimod-treated mouse CRBPI-knockout skin a more evident reduced expression of other retinoid binding proteins, such as CRABPII and RXR $\alpha$. Activation of EGFR/AKT/ERK pathway has been reported as implicated in the pathogenesis of psoriasis and influencing differentiation, proliferation and apoptosis-related genes expression [36, 37]. A possible interaction between CRBPI alone or homodimerized/heterodimerized with RAR $\alpha$ or $\mathrm{RAR} \alpha / \mathrm{RXR} \alpha$ and the consequent modulation of EGFR/ AKT/ERK pathways were previously suggested [38]. We documented in imiquimod-treated CRBPI-knockout mice the increase of AKTs, MAPKs and IL-2 and the downregulation of EGR1 gene level compared with imiquimodtreated wild-type skin. It is possible to speculate that in psoriatic epidermis a reduced or absent CRBPI expression on alternative activation or up-regulation of FOS or MAPK family genes [21, 39]. EGR1 overexpression has been identified in psoriasis and considered a gene involving in the control of benign keratinocyte hyperproloferation [40]. To further confirm the crucial role of CRBPI in maintaining keratinocyte differentiation, inflammatory balance and homeostasis of epidermis, we investigated the effects of CRBPI transfection in $\mathrm{HaCaT}$ cells, an immortalized human keratinocytes line, an useful in vitro model to evaluate keratinocyte gene modulation [41]. We documented in CRBPI-transfected HaCaT cells the increased expression of several transcriptional $\mathrm{NF}-\kappa \mathrm{B}$ and AKT-related genes and phosphorylated proteins. Those transcriptional pathways play a key role to sustain keratinocyte proliferation and the accelerated differentiation in psoriatic epidermis [42]. Our data are in accordance with previous studies, in other cell lines. CRBPI transfection in A549 lung cancer cells up-regulated proliferative and transcriptional genes, including $\mathrm{pAKT}$, pEGFR, pErk1/2, creb1 and c-jun [38]; among these, FABP5 and PPR $\beta / \delta$ trigger inflammatory changes and the deregulation of proliferation [19, 43]. Surprisingly, we documented in CRBPI-transfected HaCaT the downregulation of some of IL-related genes and proteins, as IL-2, IL-6, and IL-8. In a recent meta-analysis [20, 44], ILs and other cytokines has been suggested as potential biomarkers for psoriasis and for the response to treatment. IL-2, IL-6 are proinflammatory cytokines that induce the activation of Th cells and control the balance between Treg cells and Th17 cells [21]. We also investigated the possible role of CRBPI as susceptibility psoriatic gene (RBPI gene). RBPI maps on chromosome $3 \mathrm{q} 2$ and clusters near to PSORS5 locus $[16,45]$ a well-known psoriasis susceptibility locus. We analyzed three different SNPs and seven different haplotypes, but no significant associations could be highlighted; although other SNPs on CRBPI gene potentially associated with the disease should be further investigated, at least for the population of Central Italy we considered.

In conclusion, our results strongly support the main involvement of CRBPI in the pathobiology of psoriatic skin. In particular, increased of CRBPI expression seems to be required to sustain accumulated proliferation and abnormal differentiation of keratinocytes. Increased CRBPI expression in psoriatic epidermis may reflect the enhanced necessity of keratinocytes to accumulate retinol to sustain abnormal proliferation and transcriptional activity [39]. Finally, a direct role of CRBPI in counteracting activation of pro-inflammatory IL-related genes could be hypothesized. Strategies aimed to prevent loss of CRBPI expression and its related activity may represent an additional innovative vision aimed to increase efficacy of local and systemic retinoid-based therapies of psoriasis.
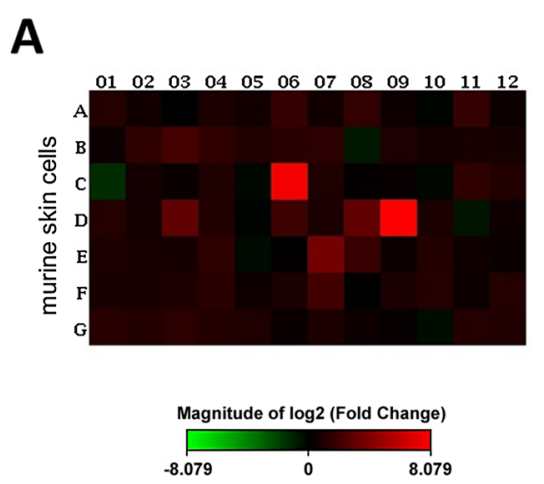

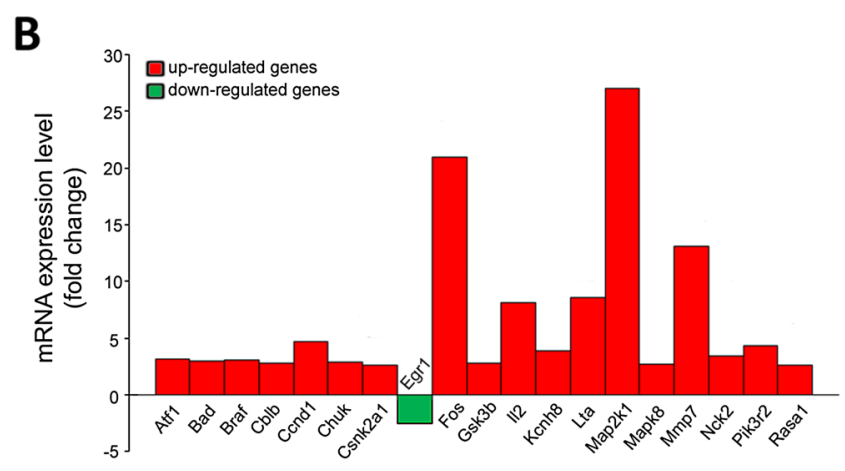

Figure 5: CRBPI deletion influences gene signaling in imiquimod-treated murine skin cells. (A) Heat map and (B) bar graph of $\mathrm{RT}^{2}$ profiler ${ }^{\mathrm{TM}} \mathrm{PCR}$ assay of EGF/PDGF-related genes in isolated murine skin of imiquimod-treated wild type and CRBPIknockout mice. Up-regulated and down-regulated genes reported in red and green, respectively. 
A

NF-kB-related genes

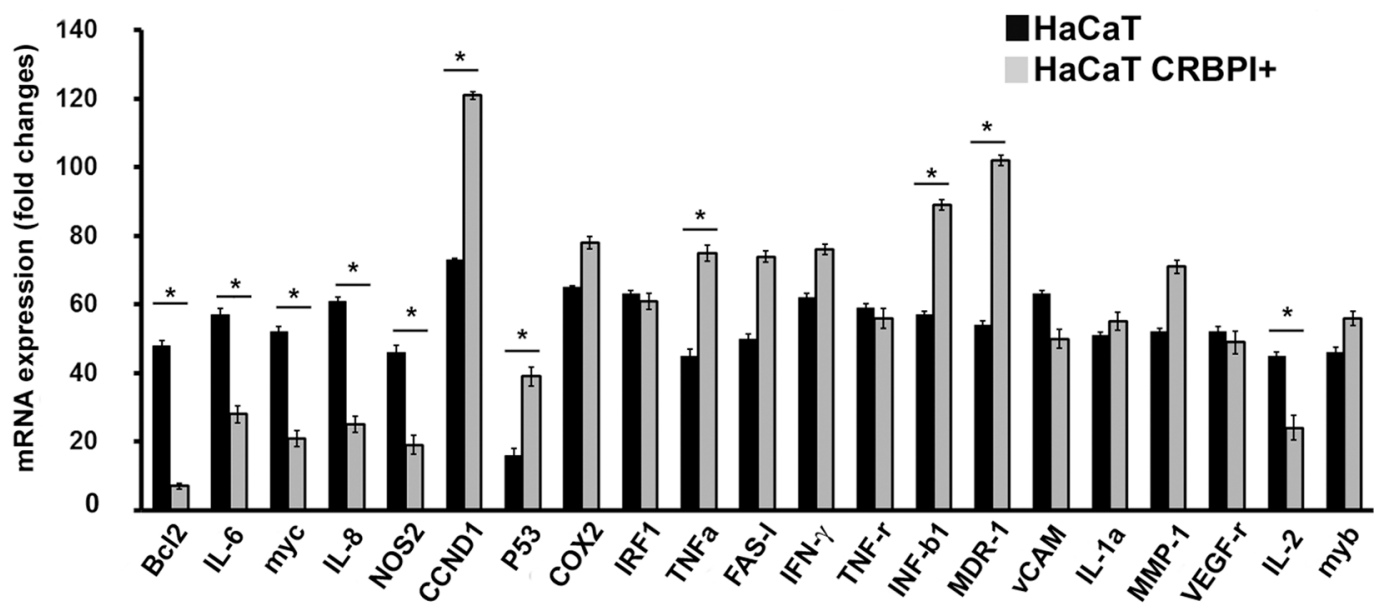

B

AKT-related genes

Hačaì

HaCaT CRBPI+

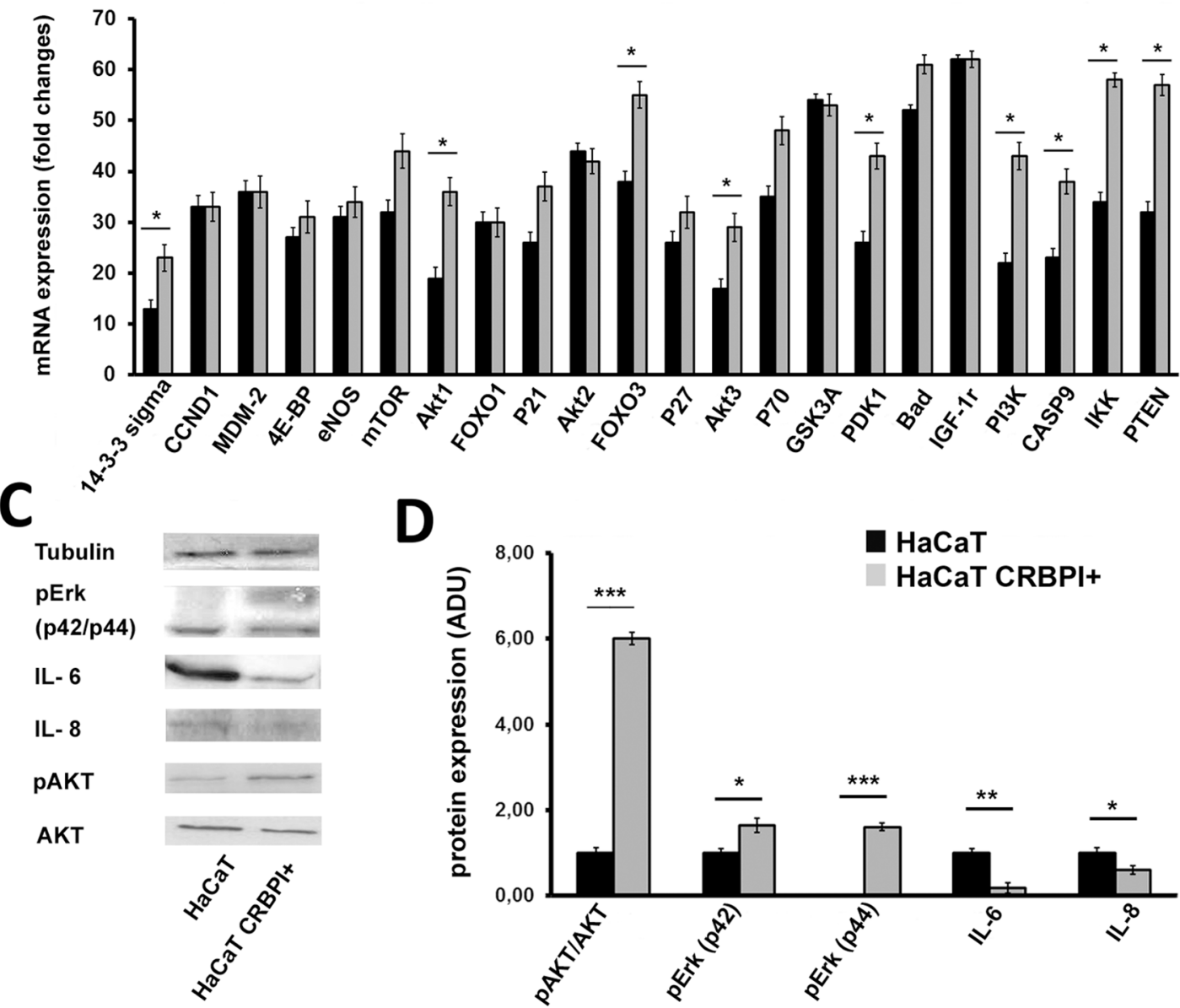

Figure 6: CRBPI transfection up-regulates NF-kB and AKT-related transcriptional gene pathway in HaCaT cells. (A-B), bar graphs of NF-kB and AKT signaling-specific genes array of CRBPI-transfected HaCaT cells. (C) Representative blots and (D) bar graphs densitometric evaluation of pAKT/AKT, pErk, IL-6 and IL-8 protein expression. Significant changes reported ${ }^{*} p<0.05,{ }^{* *} p<$ $0.001 ;{ }^{* * * *} p<0.0005$ at Student's $t$-test. 
Table 1: Demographics and disease parameters of enrolled patients

\begin{tabular}{|c|c|c|c|c|}
\hline Case (") & Age & Sex & Pasi & Arthritis \\
\hline 1 & 39 & $\mathrm{~F}$ & 13,5 & YES \\
\hline 2 & 44 & $\mathrm{M}$ & 6 & NO \\
\hline 3 & 24 & $\mathrm{~F}$ & 12,9 & YES \\
\hline 4 & 41 & $\mathrm{M}$ & 12,4 & $\mathrm{NO}$ \\
\hline 5 & 50 & $\mathrm{~F}$ & 15 & YES \\
\hline 6 & 51 & $\mathrm{M}$ & 12 & NO \\
\hline 7 & 54 & $\mathrm{M}$ & 12 & NO \\
\hline 8 & 33 & $\mathrm{M}$ & 13,5 & NO \\
\hline 9 & 55 & $\mathrm{~F}$ & 34,2 & YES \\
\hline 10 & 28 & $\mathrm{M}$ & 10 & NO \\
\hline 11 & 31 & $\mathrm{M}$ & 10 & NO \\
\hline 12 & 66 & $\mathrm{M}$ & 13 & YES \\
\hline 13 & 49 & $\mathrm{M}$ & 15,3 & YES \\
\hline 14 & 53 & $\mathrm{~F}$ & 12 & YES \\
\hline 15 & 60 & $\mathrm{M}$ & 8,7 & YES \\
\hline 16 & 48 & $\mathrm{M}$ & 12,4 & $\mathrm{NO}$ \\
\hline 17 & 32 & $\mathrm{M}$ & 10 & NO \\
\hline 18 & 44 & $\mathrm{M}$ & 15 & YES \\
\hline 19 & 42 & $\mathrm{M}$ & 7 & YES \\
\hline 20 & 57 & $\mathrm{M}$ & 9 & YES \\
\hline 21 & 60 & $\mathrm{~F}$ & 10 & NO \\
\hline 22 & 73 & $\mathrm{M}$ & 10 & YES \\
\hline 23 & 57 & $\mathrm{~F}$ & 8 & YES \\
\hline 24 & 43 & $\mathrm{M}$ & 13 & YES \\
\hline 25 & 42 & $\mathrm{M}$ & 16 & $\mathrm{NO}$ \\
\hline 26 & 42 & $\mathrm{M}$ & 12 & YES \\
\hline 27 & 49 & $\mathrm{M}$ & 10 & $\mathrm{NO}$ \\
\hline 28 & 31 & $\mathrm{M}$ & 10 & NO \\
\hline 29 & 39 & $\mathrm{M}$ & 12 & NO \\
\hline 30 & 28 & $\mathrm{M}$ & 12 & NO \\
\hline 31 & 36 & $\mathrm{~F}$ & 12 & YES \\
\hline 32 & 54 & $\mathrm{M}$ & 7 & YES \\
\hline 33 & 45 & $\mathrm{~F}$ & 4 & YES \\
\hline 34 & 64 & $\mathrm{~F}$ & 6 & YES \\
\hline 35 & 35 & $\mathrm{~F}$ & 4 & YES \\
\hline 36 & 42 & $\mathrm{M}$ & 12 & NO \\
\hline 37 & 44 & $\mathrm{M}$ & 12 & $\mathrm{NO}$ \\
\hline
\end{tabular}

(Continued) 


\begin{tabular}{ccccc}
\hline Case () & Age & Sex & Pasi & Arthritis \\
\hline 38 & 29 & M & 15 & YES \\
39 & 63 & F & 12 & NO \\
40 & 56 & M & 10 & NO \\
41 & 46 & M & 5 & YES \\
42 & F & M & 1,8 & YES \\
43 & 57 & F & 8,5 & NO \\
44 & 61 & M & 3,2 & YES \\
45 & 36 & M & 33 & NO \\
46 & 46 & F & 10,8 & NO \\
47 & 67 & M & 6,7 & YES \\
48 & 70 & M & 27,9 & NO \\
49 & 53 & M & 9,8 & NO \\
50 & 32 & F & 15,6 & NO \\
51 & 49 & M & 5,6 & YES \\
52 & 54 & M & 10,3 & NO \\
53 & 35 & M & 12,2 & NO \\
54 & 56 & F & 10,4 & NO \\
55 & 58 & M & 18,2 & NO \\
56 & 21 & F & 10,8 & NO \\
57 & 56 & 26 & NO \\
58 & 54 & 5,6 & 39,6 \\
59 & $50 S$ & & NO
\end{tabular}

(*) Cases 1-40: patients from Policlinico of Tor Vergata.

Cases 41-59. patients from Instituto San Gallicano, Rome, Italy

\section{MATERIALS AND METHODS}

\section{Study population and skin biopsies}

Fifty-nine patients (19 female and 40 male patients, mean age $47.47 \pm 12.1 \mathrm{yrs}$ ), affected by moderate-to-severe plaque-type skin psoriasis were consecutively enrolled in an open, observational study at the Dermatology Departments of Tor Vergata University of Rome and S. Gallicano Institute of Rome, Italy [20]. Demographic and clinic-pathological data reported in Table 1. Approval of the study obtained from institutional Ethical Committees and Public Health Ministry in accordance with the Declaration of Helsinki. An age- and sex- matched control group included 20 healthy untreated subjects undergoing an Institutional health surveillance program. Three mm punch biopsies obtained from lesional and non-lesional areas for morphological confirmation of the disease (see after). As control, homogeneous by gender and age, anonymous control skin sections from paraffin block archive of surgically excided non-neoplastic biopsies were also investigated ( $\mathrm{n}=13$; mean age $45.5 \pm 2.75$; range $24-58$ ).

\section{Microscopic and immunohistochemical studies of human skin}

Biopsies were fixed in 10\% formalin for $24 \mathrm{~h}$ and paraffin-embedded four- $\mu \mathrm{m}$ thick serial sections stained with Haematoxylin\&Eosin for routine histopathological examination or employed for immunohistochemistry. For the latter, sections were incubated with following primary antibodies: polyclonal rabbit anti-CRBPI (1:300; Santa Cruz Biotechnology, Texas, USA); anti-CRABPII (1:300; Bethyl Laboratories, Texas, USA); anti-RXR $\alpha$ (1:750; Abcam; UK) and anti-CK1(1:1000; Abcam) followed by biotin-labeled goat anti-rabbit secondary antibody and streptavidinhorseradish peroxidase conjugated (Ylem,1:100). Serial slides were also incubated with monoclonal mouse anti- 
CK17 (1:50; Cell Marque Corporation, CA, USA), followed by revelation with Ultravision LP Detection System (Thermo Scientific, CA, USA) [46]. Immunostaining with anti-Ki-67 mouse monoclonal antibody (clone 30-9), performed by using an automatic device (Ventana-Roche Diagnostics Milan, Italy), according to manufacturer's instructions. All immunohistochemical procedures included positive and negative controls [47].

\section{Generation of CRBPI-null mice and mutant genotyping}

Transgenic C57BL/6 mice heterozygous for CrbpI gene (50\% 129Sv and 50\% C57BL/6, line QK10) were gifted (dr Ghyselinck NB; France). To confirm homozygous CRBPI mutant mice progenies, tail tissue DNA was obtained using manufacture's extraction protocols (Qiagen, Hilden-Germany). The genotype was confirmed by reverse transcription PCR analysis, as reported [39]. Mice were kept in pathogen-free conditions and housed in a temperaturecontrolled facility with a 12 light/dark cycle. Animals fed with a commercial diet and water ad libitum. All experiments were in accordance with the ethical standards, the Declaration of Helsinki and with national and international guidelines. All experiments were approved by the Institutional Animal Care and Use Committee, and carried out according to the Italian rules (D.L. 116/92; CE. 609/86).

\section{Imiquimod-induced psoriasis and monitoring of lesions}

Twelve week-old CRBPI-knockout $(n=8)$ and wildtype mice $(n=8)$ were shaved on their back and then treated with a daily topical dose of $62.5 \mathrm{mg}$ of a commercial cream containing 5\% imiquimod (Aldara ${ }^{\mathrm{TM}}$, MEDA Pharma) for 6 consecutive days [17]. Control CRBPI-knockout and wild type mice $(n=3)$ were treated similarly with a control vehicle cream (Vaseline Bianca, Polifarma Benessere). Imiquimod-treated mice received also the injection of 300 $\mu \mathrm{l}$ of PBS at day 3 and 4, to prevent imiquimod treatment induced systemic adverse effects in C57BL/6 mice [17]. To evaluate the severity of skin lesions, we used a scoring system based on the clinical Psoriasis Area and Severity Index (PASI), consisting of the following parameters: erythema, scaling and skin thickness. Those parameters were scored independently (scale from 0 to 4 : 0 , none; 1 , slight; 2, moderate; 3, marked and 4, very marked) and cumulatively as PASI $[17,18]$.

\section{Microscopic and immunohistochemical analysis of mice skin}

After 6 days, mice were sacrificed by cervical dislocation and dorsal lesional skin was collected for histological examination. Formalin-fixed, paraffinembedded sections from skin samples were stained with Haematoxylin\&Eosin and examined in a blinded manner by two dermatopathologists. Histopathologic features of psoriasis [35], as hyperkeratosis, parakeratosis, papillomatosis, spongiosis, microabscesses neutrophils and dilated dermal blood vessels were evaluated by using a grading system in arbitrary units as follows: absent presence (0), weak (1), moderate (2), strong (3). Presence of hypogranulosis, acanthosis (as number of epidermal layers in at least ten randomly selected fields) were also evaluated [35].

For immunohistochemistry, serial $4-\mu \mathrm{m}$ thick mouse skin sections were deparaffinized, rehydrated and, after antigen retrieval and nonspecific peroxidase blocking, incubated with rabbit polyclonal anti-CRBP-I, anti-CRABP-II, anti-RXRa and anti-CK1 (see Human immunohistochemistry section), rabbit monoclonal anti-Ki-67 (Novus Biologicals, Littleton, CO, USA) and anti-CK17 (ProteinGroupTech, Manchester, United Kingdom). Positive and negative controls were included to confirm the consistency of the analysis. Semiquantitative evaluation of investigated parameters was performed independently from two researchers by using an arbitrary grading system, as reported [48].

\section{RNA extraction and gene analysis of mouse skin}

Total RNA from the mouse back skin was extracted using TRI ${ }^{\circledR}$ reagent (Sigma-Aldrich, St. Louis, USA) according to the manufacturer's instructions [49]. RT ${ }^{2}$ profiler PCR arrays (Qiagen, Hilden, Germany) for a gene panel of mouse (PAMM-040ZA; Supplementary Table 3) epidermal growth factor and platelet-derived growth factor-related pathways were performed and data analyzed using the manufacturer's integrated webbased software package using $\Delta \Delta \mathrm{C}_{\mathrm{t}}$-based fold-change calculation (Qiagen) in triplicate experiments.

\section{Cell transfection}

Immortalized human keratinocyte cells $\mathrm{HaCaT}$, (Lonza, Milano, Italy) maintained in D-MEM (Lonza Bio Pharma AG, Switzerland) were transfected by using a vector pTargeT Mammalian expression system carrying the whole sequence of CRBPI gene (NM_002899) and the gene for G418 resistance (Promega, Italy), or the G418-resistance gene alone. After 20 days, stable transfected clones were collected in G418-containing medium and tested by PCR and western blot. The correct plasmid sequence was confirmed by Sanger sequencing. Experimental procedures were repeated by using different transfected clones, which gave similar results.

\section{Gene and protein expression analysis in $\mathrm{HaCaT}$ cells}

Gene expression analysis of $\mathrm{HaCaT}$ cells was performed using Signosis array (Signosis, Inc. Santa Clara, CA, USA). Briefly, RNA was extracted, reverse-transcribed into cDNA in the presence of biotin-dUTP and a profile of 
24 genes for human AKT and NF- $\kappa \mathrm{B}$ pathway cDNA plate array (Signosis) respectively, was carried out through the detection of streptavidin-HRP. Luminescence reported as relative light units (RLUs) on a microplate luminometer, according to the manufacturer' instruction. Experiments performed in triplicate. For western blot analyses, after extraction, proteins were blotted onto nitrocellulose membranes and incubated with anti-phosphorylated v-akt murine thymoma viral oncogene homolog (pAkt Ser ${ }^{473}$ ), anti-AKT (pan), anti-phosphorylated extracellular-signalregulated kinases (pErk1/2; Cell Signaling Technology, Danvers, MA, USA), anti-interleukin 6 (IL-6, R\&D Systems, Minneapolis, USA), anti-interleukin 8 (IL-8, Abcam, Cambridge, UK) and anti-total tubulin antibody (Sigma-Aldrich). Revelation and densitometric blot analysis were performed in three independent experiments. Membranes were reblotted with anti-tubulin to ensure equal loading. Akt activity was expressed as phospho/total protein ratio. Results are mean values \pm SEM of the three different experiments. ${ }^{*} p<0.05,{ }^{* *} p<0.005$ and ${ }^{* * *} p<0,001$. Abbreviations: ADU, arbitrary densitometric units.

\section{Genetic analysis}

The CRBPI gene analysis, were enrolled 890 Italian subjects including patients with psoriasis $(n=400)$ and healthy subjects $(n=490)$. Psoriasic patients were recruited from the Department of Dermatology "Tor Vergata" University of Rome, IDI-Istituto Dermopatico dell'Immacolata, Fatebenefratelli and San Gallicano Hospital, Rome, Italy. The control group were recruited in a wide cohort of blood donors originating from the same geographical area of the cases. The study was approved by the ethics committee of each participating institute and the signature of the informed consent was obtained from all the participants. Genomic DNA was extracted from peripheral blood using standard procedures. The International HapMap Project "HapMap3 Genome Browser release \#2 (Phase 3-genotypes, frequencies \& $L D$ )" has been used to perform a "in silico" SNPs selection, in order to identify the fewest number of SNPs able to represent the maximum variability of the region $3 \mathrm{q} 23$. In particular, we have selected 4 different SNPs located on RBP1 gene (rs184157 A/G; rs295493 A/G; rs893704 G/T and rs2071387 C/T). The genotyping analysis was performed by TaqMan assays on a 7500 Fast Real Time PCR device (Applied Biosystems, CA, USA). Each Real Time PCR run contained a negative control and three positive control samples were previously confirmed by direct sequencing. The genotyping data obtained by Real Time PCR were interpreted by using the Sequence Detection System 2.1 software (Applied Biosystems).

\section{Statistical analysis}

All results were expressed as the arithmetical mean \pm SEM. Data were analyzed by one-way analysis of variance (ANOVA) followed from a Bonferroni post hoc test and using the Student $t$-test. The differences were considered statistically significant for $p$ values $<0.05$. Statistical genetic analysis was performed by standard $2 \times 2$ table and Fisher's exact text, considering allele, genotype and haplotype frequencies of all tested variations. Odds Ratios (OR) were calculated and allele and haplotype analysis in unrelated samples by using the UNPHASED software [3].

\section{Author contributions}

Conceptualization: Gaetana Costanza, Augusto Orlandi, Amedeo Ferlosio, Luca Bianchi.

Data curation: Gaetana Costanza, Chiara Tarquini, Amedeo Ferlosio.

In vivo experiments: Daniela Passeri, Chiara Tarquini, Mauro Bavetta, Di Stefani Alessandro.

In vitro experiments: Elena Doldo, Sara Agostinelli, Raffaella Cascella, Emiliano Giardina.

Formal analysis: Gaetana Costanza, Chiara Tarquini.

Funding acquisition: Augusto Orlandi.

Methodology: Gaetana Costanza, Elena Doldo, Daniela Passeri.

Project administration: Augusto Orlandi, Luca Bianchi, Aldo Morrone.

Resources: Gaetana Costanza, Amedeo Ferlosio, Chiara Tarquini.

Supervision: Augusto Orlandi, Luca Bianchi, Elena Campione, Emiliano Giardina, Aldo Morrone.

Validation: Amedeo Ferlosio, Alessandro Di Stefani, Claudio Bonifati.

Visualization: Gaetana Costanza, Elena Doldo, Amedeo Ferlosio, Augusto Orlandi.

Writing \pm original draft: Gaetana Costanza, Chiara Tarquini, Augusto Orlandi.

Writing \pm review \& editing: Gaetana Costanza, Amedeo Ferlosio, Chiara Tarquini, Elena Doldo, Daniela Passeri, Raffaella Cascella, Alessandro Di Stefani, Claudio Bonifati, Sara Agostinelli, Federica Centofanti, Emiliano Giardina, Mauro Bavetta, Elena Campione, Luca Bianchi, Pietro Donati, Aldo Morrone and Augusto Orlandi.

\section{ACKNOWLEDGMENTS}

The authors wish to thank M. Maccarone, President of Italian Psoriatic Patient Association (ADIPSO), for providing access to database, and S. Cappelli for providing technical collaboration.

\section{CONFLICTS OF INTEREST}

The authors certify that there is no conflicts of interest with any financial organization regarding the material discussed in the manuscript. 


\section{FUNDING}

This work was partially funded by the Italian Ministry of Health (2008).

\section{REFERENCES}

1. Wagner EF, Schonthaler HB, Guinea-Viniegra J, Tschachler E. Psoriasis: what we have learned from mouse models. Nat Rev Rheumatol. 2010; 6:704-14.

2. Piaserico S, Cazzaniga S, Chimenti S, Giannetti A, Maccarone M, Picardo M, Peserico A, Naldi L; Psocare Study Group. Efficacy of switching between tumor necrosis factor-alfa inhibitors in psoriasis: results from the Italian Psocare registry. J Am Acad Dermatol. 2014; 70:257-262 e3.

3. Bianchi L, Costanza G, Campione E, Ruzzetti M, Di Stefani A, Diluvio L, Giardina E, Cascella R, Cordiali-Fei P, Bonifati C, Chiricozzi A, Novelli G, Ensoli F, Orlandi A. Biomolecular index of therapeutic efficacy in psoriasis treated with anti-TNF- $\alpha$ agents. G Ital Dermatol Venereol. 2018; 153:316-25.

4. Lowes MA, Bowcock AM, Krueger JG. Pathogenesis and therapy of psoriasis. Nature. 2007; 445:866-73.

5. Chiricozzi A, Saraceno R, Novelli L, Fida M, Caso F, Scarpa R, Costa L, Perricone R, Romanelli M, Chimenti $\mathrm{S}$, Chimenti MS. Small molecules and antibodies for the treatment of psoriasis: a patent review (2010-2015). Expert Opin Ther Pat. 2016; 26:757-766.

6. Segaert S, Hermans C. Clinical signs, pathophysiology and management of cutaneous side effects of anti-tumor necrosis factor agents. Am J Clin Dermatol. 2017; 18:771-87.

7. Noy N. Non-classical transcriptional activity of retinoic acid. Subcell Biochem. 2016; 81:179-199.

8. Ghyselinck NB, Båvik C, Sapin V, Mark M, Bonnier D, Hindelang C, Dierich A, Nilsson CB, Håkansson H, Sauvant P, Azaïs-Braesco V, Frasson M, Picaud S, Chambon P. Cellular retinol-binding protein I is essential for vitamin A homeostasis. EMBO J. 1999; 18:4903-14.

9. Doldo E, Costanza G, Agostinelli S, Tarquini C, Ferlosio A, Arcuri G, Passeri D, Scioli MG, Orlandi A. Vitamin $A$, cancer treatment and prevention: the new role of cellular retinol binding proteins. Biomed Res Int. 2015; 2015:624627.

10. Napoli JL. Cellular retinoid binding-proteins, CRBP, CRABP, FABP5: effects on retinoid metabolism, function and related diseases. Pharmacol Ther. 2017; 173:19-33.

11. Blomhoff R. Transport and metabolism of vitamin A. Nutr Rev. 1994; 52:S13-23.

12. Busch C, Siegenthaler G, Vahlquist A, Nordlinder H, Sundelin J, Saksena P, Eriksson U. Expression of cellular retinoid-binding proteins during normal and abnormal epidermal differentiation. J Invest Dermatol. 1992; 99:795-802.
13. Karlsson T, Virtanen M, Sirsjö A, Rollman O, Vahlquist A, Törmä H. Topical retinoic acid alters the expression of cellular retinoic acid-binding protein-I and cellular retinoic acid-binding protein-II in non-lesional but not lesional psoriatic skin. Exp Dermatol. 2002; 11:143-52.

14. Törmä H, Karlsson T, Michaëlsson G, Rollman O, Vahlquist A. Decreased mRNA levels of retinoic acid receptor alpha, retinoid $\mathrm{X}$ receptor alpha and thyroid hormone receptor alpha in lesional psoriatic skin. Acta Derm Venereol. 2000; 80:4-9.

15. Siegenthaler G, Saurat JH, Morin C, Hotz R. Cellular retinol- and retinoic acid-binding proteins in the epidermis and dermis of normal human skin. Br J Dermatol. 1984; 111:647-54.

16. Enlund F, Samuelsson L, Enerbäck C, Inerot A, Wahlström J, Yhr M, Torinsson A, Riley J, Swanbeck G, Martinsson T. Psoriasis susceptibility locus in chromosome region $3 q 21$ identified in patients from southwest Sweden. Eur J Hum Genet. 1999; 7:783-90.

17. van der Fits L, Mourits S, Voerman JS, Kant M, Boon L, Laman JD, Cornelissen F, Mus AM, Florencia E, Prens EP, Lubberts E. Imiquimod-induced psoriasis-like skin inflammation in mice is mediated via the IL-23/IL-17 axis. J Immunol. 2009; 182:5836-45.

18. El Malki K, Karbach SH, Huppert J, Zayoud M, Reissig S, Schüler R, Nikolaev A, Karram K, Münzel T, Kuhlmann CR, Luhmann HJ, von Stebut E, Wörtge S, et al. An alternative pathway of imiquimod-induced psoriasis-like skin inflammation in the absence of interleukin-17 receptor a signaling. J Invest Dermatol. 2013; 133:441-51.

19. Romanowska M, Reilly L, Palmer CN, Gustafsson MC, Foerster J. Activation of PPARbeta/delta causes a psoriasislike skin disease in vivo. PLoS One. 2010; 5:e9701.

20. Cordiali-Fei P, Bianchi L, Bonifati C, Trento E, Ruzzetti M, Francesconi F, Bultrini S, D’Agosto G, Bordignon V, Francavilla V, Tripiciano A, Chiricozzi A, Campione E, et al. Immunologic biomarkers for clinical and therapeutic management of psoriasis. Mediators Inflamm. 2014; 2014:236060.

21. Tan Y, Qi Q, Lu C, Niu X, Bai Y, Jiang C, Wang Y, Zhou $\mathrm{Y}, \mathrm{Lu} \mathrm{A}$, Xiao C. Cytokine imbalance as a common mechanism in both psoriasis and rheumatoid arthritis. Mediators Inflamm. 2017; 2017:2405291.

22. van de Kerkhof PC. Update on retinoid therapy of psoriasis in: an update on the use of retinoids in dermatology. Dermatol Ther. 2006; 19:252-63.

23. Rush MG, Ul-Haq R, Chytil F. Opposing effects of retinoic acid and dexamethasone on cellular retinol-binding protein ribonucleic acid levels in the rat. Endocrinology. 1991; 129:705-09.

24. Ong DE. Cellular transport and metabolism of vitamin A: roles of the cellular retinoid-binding proteins. Nutr Rev. 1994; 52:S24-31. 
25. Lee DD, Stojadinovic O, Krzyzanowska A, Vouthounis C, Blumenberg M, Tomic-Canic M. Retinoid-responsive transcriptional changes in epidermal keratinocytes. J Cell Physiol. 2009; 220:427-39.

26. Giguère V. Retinoic acid receptors and cellular retinoid binding proteins: complex interplay in retinoid signaling. Endocr Rev. 1994; 15:61-79.

27. Asselineau D, Bernard BA, Bailly C, Darmon M. Retinoic acid improves epidermal morphogenesis. Dev Biol. 1989; 133:322-35.

28. Riahi RR, Bush AE, Cohen PR. Topical retinoids: therapeutic mechanisms in the treatment of photodamaged skin. Am J Clin Dermatol. 2016; 17:265-76.

29. Soini Y, Kamel D, Pääkkö P, Lehto VP, Oikarinen A, Vähäkangas KV. Aberrant accumulation of p53 associates with Ki67 and mitotic count in benign skin lesions. Br J Dermatol. 1994; 131:514-20.

30. Weinstein GD, McCullough JL, Ross PA. Cell kinetic basis for pathophysiology of psoriasis. J Invest Dermatol. 1985; 85:579-83.

31. Hendriks AG, van der Velden HM, Wolberink EA, Seyger MM, Schalkwijk J, Zeeuwen PL, de Jong EM, Pasch MC, van Erp PE, van de Kerkhof PC. The effect of adalimumab on key drivers in the pathogenesis of psoriasis. Br J Dermatol. 2014; 170:571-80.

32. Shi X, Jin L, Dang E, Chang T, Feng Z, Liu Y, Wang G. IL-17A upregulates keratin 17 expression in keratinocytes through STAT1- and STAT3-dependent mechanisms. J Invest Dermatol. 2011; 131:2401-08.

33. Szeimies RM, Gerritsen MJ, Gupta G, Ortonne JP, Serresi S, Bichel J, Lee JH, Fox TL, Alomar A. Imiquimod 5\% cream for the treatment of actinic keratosis: results from a phase III, randomized, double-blind, vehicle-controlled, clinical trial with histology. J Am Acad Dermatol. 2004; 51:547-55.

34. Nickoloff BJ, Qin JZ, Nestle FO. Immunopathogenesis of psoriasis. Clin Rev Allergy Immunol. 2007; 33:45-56.

35. Ardigo M, Cota C, Berardesca E, González S. Concordance between in vivo reflectance confocal microscopy and histology in the evaluation of plaque psoriasis. J Eur Acad Dermatol Venereol. 2009; 23:660-67.

36. Chandra A, Ray A, Senapati S, Chatterjee R. Genetic and epigenetic basis of psoriasis pathogenesis. Mol Immunol. 2015; 64:313-23.

37. Chamcheu JC, Chaves-Rodriquez MI, Adhami VM, Siddiqui IA, Wood GS, Longley BJ, Mukhtar H. Upregulation of $\mathrm{PI} 3 \mathrm{~K} / \mathrm{AKT} / \mathrm{mTOR}, \mathrm{FABP} 5$ and PPARbeta/delta in human psoriasis and imiquimod-induced murine psoriasiform dermatitis model. Acta Derm Venereol. 2016; 96:854-56.

38. Doldo E, Costanza G, Ferlosio A, Pompeo E, Agostinelli S, Bellezza G, Mazzaglia D, Giunta A, Sidoni A, Orlandi A. High expression of cellular retinol binding protein-1 in lung adenocarcinoma is associated with poor prognosis. Genes Cancer. 2015; 6:490-502. https://doi.org/10.18632/genesandcancer.89.
39. Passeri D, Doldo E, Tarquini C, Costanza G, Mazzaglia D, Agostinelli S, Campione E, Di Stefani A, Giunta A, Bianchi L, Orlandi A. Loss of CRABP-II characterizes human skin poorly differentiated squamous cell carcinomas and favors DMBA/TPA-induced carcinogenesis. J Invest Dermatol. 2016; 136:1255-66.

40. Fang M, Wee SA, Ronski K, Fan H, Tao S, Lin Q. Evidence of EGR1 as a differentially expressed gene among proliferative skin diseases. Genomic Med. 2007; 1:75-85.

41. Smolińska E, Moskot M, Jakóbkiewicz-Banecka J, Węgrzyn G, Banecki B, Szczerkowska-Dobosz A, Purzycka-Bohdan D, Gabig-Cimińska M. Molecular action of isoflavone genistein in the human epithelial cell line HaCaT. PLoS One. 2018; 13:e0192297.

42. Tsuruta D. NF-kappaB links keratinocytes and lymphocytes in the pathogenesis of psoriasis. Recent Pat Inflamm Allergy Drug Discov. 2009; 3:40-48.

43. Zenz R, Wagner EF. Jun signalling in the epidermis: from developmental defects to psoriasis and skin tumors. Int $\mathbf{J}$ Biochem Cell Biol. 2006; 38:1043-49.

44. Bai F, Zheng W, Dong Y, Wang J, Garstka MA, Li R, An J, Ma H. Serum levels of adipokines and cytokines in psoriasis patients: a systematic review and meta-analysis. Oncotarget. 2018; 9:1266-1278. https://doi.org/10.18632/oncotarget.22260.

45. Hewett D, Samuelsson L, Polding J, Enlund F, Smart D, Cantone K, See CG, Chadha S, Inerot A, Enerback C, Montgomery D, Christodolou C, Robinson P, et al. Identification of a psoriasis susceptibility candidate gene by linkage disequilibrium mapping with a localized single nucleotide polymorphism map. Genomics. 2002; 79:305-14.

46. Soda R, Costanzo A, Cantonetti M, Orlandi A, Bianchi L, Chimenti S. Systemic therapy of primary cutaneous B-cell lymphoma, marginal zone type, with rituximab, a chimeric anti-CD20 monoclonal antibody. Acta Derm Venereol. 2001; 81:207-08.

47. Stasi MA, Scioli MG, Arcuri G, Mattera GG, Lombardo K, Marcellini M, Riccioni T, De Falco S, Pisano C, Spagnoli LG, Borsini F, Orlandi A. Propionyl-L-carnitine improves postischemic blood flow recovery and arteriogenetic revascularization and reduces endothelial NADPH-oxidase 4-mediated superoxide production. Arterioscler Thromb Vasc Biol. 2010; 30:426-35.

48. Orlandi A, Bianchi L, Costanzo A, Campione E, Giusto Spagnoli L, Chimenti S. Evidence of increased apoptosis and reduced proliferation in basal cell carcinomas treated with tazarotene. J Invest Dermatol. 2004; 122:1037-41.

49. Ciuffreda L, Di Sanza C, Cesta Incani U, Eramo A, Desideri M, Biagioni F, Passeri D, Falcone I, Sette G, Bergamo P, Anichini A, Sabapathy K, McCubrey JA, et al. The mitogen-activated protein kinase (MAPK) cascade controls phosphatase and tensin homolog (PTEN) expression through multiple mechanisms. J Mol Med (Berl). 2012; 90:667-79. 